\title{
Assessment of Differently Abled Student's Inferiority Complex at School Level in the State of West Bengal, India: An Item Analysis
}

\author{
Ranajit Dhara; \\ Research Scholar, Department of Education, Sidho-Kanho-Birsha University, Purulia, \\ West Bengal, India, 723104 \\ E-mail Id: ranajitedu@gmail.com \\ Contact No: 0973417046
}

\section{Uday Bauri}

Assisstant Professor, Department of Education, Narasinha Dutta College, Howrah, West Bengal , India, 711101

E-mail Id: udaybauri737@gmail.com

Contact No: 0973417046

\section{Dr. Amarnath Das}

Assistant Professor, Dept. of Education, Arsha College, Purulia- 723201,

West Bengal, India

Email: amarnathdas2011@gmail.com

Contact No: 08617642295

\section{Dr. Nandini Banerjee}

Assistant Professor, Dept. of Education, Kazi Nazrul University, Asansol,

West Bengal, India, 713340

Email: nandinibanerjee11@gmail.com

Contact No: 08250990832

Article History: Received: 10 November 2020; Revised 12 January 2021 Accepted: 27 January 2021; Published online: 5 April 2021

\begin{abstract}
:
In this world, everyone starts their life with some feelings of inferiority. Later success or failure is judged by the ability to adjust the feeling of inferiority to the demands of their life. Normally it requires the control and articulates of one's inferiority complex in order to achieve a beneficial balance in emotional maturity (Lin, 1997). The present study aims to explore the level of Inferiority Complex of the Differently Abled Students and their opinion about each item of inferiority measuring questionnaire constructed by investigators. The tool was standardized by Reliability. The investigator selected 149 Differently Abled Students from Special and General School in West Bengal. After the analysis and interpretation of their given data, the investigator concludes that the moderate level of Inferiority Complex of the Differently Abled Students. The study also revealed that according to most of the Differently Abled Students, Sometimes Rarely and Not at all opinions gave on most of the Statements.
\end{abstract}

Keywords: Inferiority Complex, Differently Abled Students. 


\section{Introduction}

Everyone wants to live a physically and mentally healthy life. Everyone is the member of this society. As a member of society, they create goals in everyone's life and they try to fulfill life's goals (Uralovich 2019). In order to survive in this world, self-control is very important. In this case, effective participation and self-control are very basic features (Mishra 2018). Once upon a time, we felt the inferiority complex through comparisons between our classmates. However, it is very difficult to observe psychologically from that infinity. it weakens one's life (Kalavani 2017). It is most likely that at a particular moment everyone will feel through their pain and think no one will understand it (Han 2011). That feel is inferiority complex. At first, developed the Infinity Complex in his Personality Development Theory. He believes that infinity feelings in humans are a kind of universality and that it affects a person's ability and work ethic (Alphen 1969). The Infinity Complex is a kind of conscious and subconscious mind. Which is the mind of the person substitutes himself badly to others?. According to psychologists, some traits can explain a person's inferiority complex by subconscious and self-actualization. There are different types of physically challenged versions in our society. Notable among them is the Visual, Orthopedic, Deaf and Drum defect Person (Dhara and Barman 2020). Inferiority complex is a type of social anxiety or anxiety disorder that describes a person's shame, i.e. the manifestation of self-consciousness in different social objects and the manifestation of different disorders by deep anxiety (Sumarsono 2019). Intense, persistent and chronic worry can be seen in people who suffer from infertility complex. Also, the level of fear, anxiety in a person is manifested through his work. Infinity gives to conscious self-assured and self-evaluating ideas in the individual (Ikram and Waheed 2018). The Inferiority Complex may be a kind of Strengthening and Strangulating and Crushing Condition of the Person (Ala 1957).

\section{Review of Related Literature}

In the study "Personality traits among Hearing and Speech impaired Students and Normal Students: A Review," Banerjee (2018) concerned with the conditions or relationship that exists, to study personality factors of hearing-impaired students and speech impaired students.

In the study "Problems of Children with Special Needs (CWSNs) in Accessing the Education: Role of Barrier-free Environment - A Case Study of India," Devi and Reddy (2016) said that the problems of the CWSNs in the field of education, problems of the teachers in dealing with the children, parents' opinions towards the works of the schools in order to education to be acceptable to their CSWN. In the study "Application of IoT to improve the lifestyle of Differently Abled people," Varghese (2016) revealed that the Internet of Things (IoT) can help the physically disabled people to move to surround, visually disabled people to reach their objects with the help of guidelines, the deaf and dumb people to communicate in better means so that the speller and listener may be easy with each other. In the study "Analyzing Educational Status of Children with Disability and Identifying Critical Intervention to Promote their Enrollment, Retention and Success in Schools," Mishar et al (2014) revealed that Children with disability are despoil of school education because of various causes i.e. poor health, least consciousness status of the parents, family economy, school environment, 
psychological problem, etc. In the study "Effect Of Mainstreaming Education On The Academic Achievement Of Mildly Impaired Lower Basic Three Pupils In Northwest Nigeria," Ibrahim and Okopi (2014) found that there is a significant difference between mildly impaired and non-impaired pupils on Mathematics, English Language, Social Science academic achievement in northwest Nigeria. Idrees and Ilyas (2012) approached in their study "Discrimination and Stigmatization of Physically Disabled Student in a General Educational Environment in Pakistan: A Case Study" that most of the students with mobility impairments seemed positive towards life and admitted that general education had promoted their self-confidence and self-esteem.

\section{Need and Significance of the Study}

Differently Abled Students are decreasing their self-worth and self-esteem through daily comparison and competition. The irrational thoughts and inferiority complexes that result from the above in their environment are able to destroy them as well as their relationships with others. This research is valuable as it will attempt to help them gain a more positive attitude by converting their irrational thoughts into rational ones.

The present study has proposed for administrators, teachers, parents, planners and members of society who deal with Differently Abled Students. The present study revealed various learning and adjustment problems of the Differently Abled Students. Regarding their problems the teachers, parents, planner, administrators and their classmates have to be made aware so that they can perform their respective roles to help them to remove these problems. The researcher thinks this study also will help a researcher dealing with the topic, to a great extent, to know the level of Inferiority Complex of Differently Abled Students in the state of West Bengal.

\section{Objective of the Study:}

To examined the level of Inferiority Complex among the Differently Abled School Students.

\section{Hypothesis of the Study:}

Ho1. There would not have a favorable level of Inferiority Complex among the Differently Abled Students.

\section{Operational Definition of the Terms:}

\section{Differently Abled Students}

By Different Abled Students, we mean those students who are physically handicapped but who are able and work in different ways in their own capability. Visionless, Orthopedic, Deaf and Dumb have physically defaulted but they can make their way of life easier by enabling them in a different way.

\section{Inferiority complex}

It is one of the most psychological feelings of any weak person. In other way say that a person with an inferiority complex does not work properly. So they have grown the lack of self-worthiness and self confidence attitude. Inferiority complex means lack of self-portends, lack of self-esteem lack of self confidence. So we can say that the inferiority complex hinders the full development of the individual's inherent strength or power. 


\section{Methodology of the Study}

The Descriptive type research design has been adopted in the present study. Therefore, naturally, the investigators have been applied different tools, techniques, strategies and methods of descriptive survey research to collect, analyze and interpret the collected data.

Population of the Study: All Differently Abled Students of School level have been examined as the population for the present study.

Sample and Sampling Procedure: The researchers have selected only 149 students among the all Differently Abled Students who were studying at the School level (Normal School and Special School) in the state of West Bengal as a sample for this present study. In the present study, Stratified random sampling technique has been used in the selection of the sample.

Tool of the Study: Inferiority Complex measuring Questionnaire as tool have used for collecting the data by the investigators in the present study. The Inferiority Complex measuring Questionnaire embody of 30 items with the combination of positive (19) and negative (11) items and that has been developed on the basis of Likert's five-point scale i.e. Always (A), Often (O), Sometimes (S), Rarely (R), Not at All (N.A).

Techniques of Data Analysis: The investigators have used Mean and S.D. for analyzing the data in this present study.

\section{Results and Discussion}

HO$_{1}$ : There would not have high favorable level of Inferiority Complex of Differently Abled School Students in west Bengal.

Analysis of the level of Inferiority Complex of Differently Abled School Students in west Bengal on the basis of cut off point

Table No-1: Shows the Mean and S.D of Total Differently Abled School Students

\begin{tabular}{|c|c|c|c|}
\hline Group & Number & Mean & Std. Deviation \\
\hline Person & 149 & 81.94 & 15.76 \\
\hline
\end{tabular}

$$
\begin{gathered}
\mathbf{M} \pm \sigma \\
\mathbf{M}+\sigma=81.94+15.76=\mathbf{9 7 . 7 0} \\
\mathbf{M}-\sigma=81.94-15.76=\mathbf{6 6 . 1 8}
\end{gathered}
$$

Table No-2; Show the level of Inferiority Complex of Differently Abled School

Students in west Bengal on the basis of cut off point

\begin{tabular}{|c|c|c|c|}
\hline Scores & Frequency & Percentage & Level of Inferiority Complex \\
\hline Above-97.70 & 23 & $15.44 \%$ & High \\
\hline Between-66.18 to 97.70 & 100 & $67.11 \%$ & Moderate \\
\hline Below- 66.18 & 26 & $17.45 \%$ & Low \\
\hline Total & 149 & $100 \%$ & \\
\hline
\end{tabular}

On the basis of Cut off Point, from the above table, we can see that out of the total 149 Differently Abled School Students, 15.44\% Students have scored Above 97.70, 67.11\% 
Students have scored between 66.18 to 97.70 and $66.18 \%$ Students have scored Below 66.18 on the Inferiority Complex measuring Questionnaire constructed by the researchers for the Differently Abled School Students. Therefore, we can see that the maximum percentage $(67.11 \%)$ of Students have scored Between 66.18 to 97.70 , which indicates that the level of Inferiority Complex of the Differently Abled Students is being Moderate in the state of West Bengal at School Level.

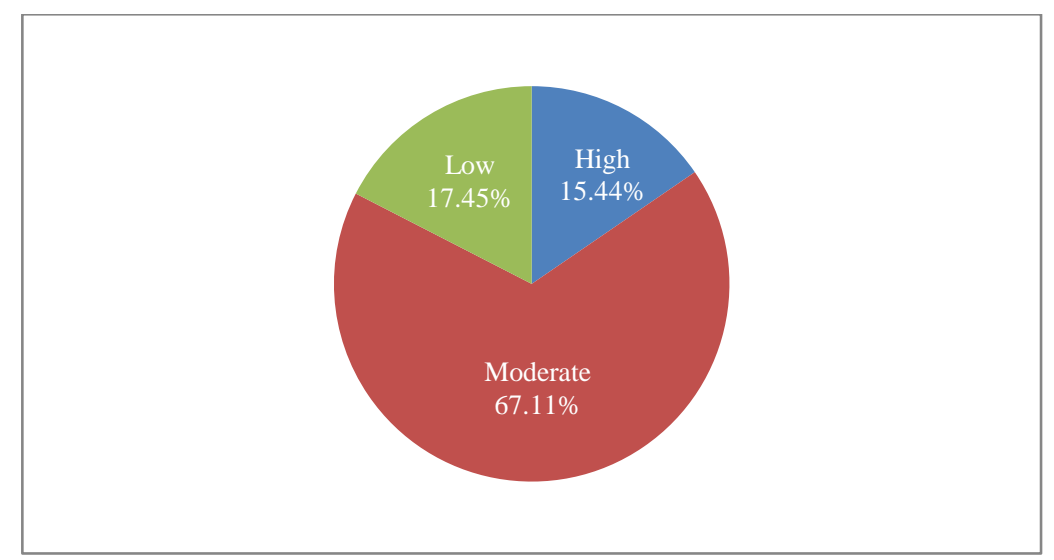

Figure: 1. Graphical representation of the level of Inferiority Complex among Differently Abled School Students on basis of Cut off point

Item wise analysis of the levels of Inferiority Complex among Differently Abled School Students

\begin{tabular}{|c|c|c|c|c|}
\hline $\begin{array}{l}\text { SL. } \\
\text { No. }\end{array}$ & Items/Statements & $\begin{array}{l}\text { Levels of } \\
\text { Agreement }\end{array}$ & Frequency & $\begin{array}{l}\text { Percentage } \\
(\%)\end{array}$ \\
\hline \multirow[t]{5}{*}{1.} & \multirow{5}{*}{$\begin{array}{l}\text { I don't want to go out of home for my physical } \\
\text { defectiveness }\end{array}$} & Always & 10 & 6.71 \\
\hline & & Often & 27 & 18.12 \\
\hline & & Sometimes & 42 & 28.19 \\
\hline & & Rarely & 31 & 20.81 \\
\hline & & Not at All & 39 & 26.17 \\
\hline \multirow[t]{5}{*}{2} & \multirow[t]{5}{*}{ I feel inferior in any to subject } & Always & 9 & 6.04 \\
\hline & & Often & 28 & 18.79 \\
\hline & & Sometimes & 48 & 32.21 \\
\hline & & Rarely & 31 & 20.81 \\
\hline & & Not at All & 33 & 22.15 \\
\hline \multirow[t]{5}{*}{3} & \multirow[t]{5}{*}{ My relatives behave well with me } & Always & 89 & 59.73 \\
\hline & & Often & 42 & 28.19 \\
\hline & & Sometimes & 9 & 6.04 \\
\hline & & Rarely & 5 & 3.36 \\
\hline & & Not at All & 4 & 2.68 \\
\hline \multirow[t]{5}{*}{4} & \multirow{5}{*}{$\begin{array}{l}\text { I see that most of the people of society not give me } \\
\text { importance }\end{array}$} & Always & 7 & 4.70 \\
\hline & & Often & 25 & 16.78 \\
\hline & & Sometimes & 21 & 14.09 \\
\hline & & Rarely & 45 & 30.20 \\
\hline & & Not at All & 51 & 34.23 \\
\hline
\end{tabular}




\begin{tabular}{|c|c|c|c|c|}
\hline \multirow[t]{5}{*}{5} & \multirow[t]{5}{*}{ My sisters and brothers are dearer than me to my parent } & Always & 11 & 7.38 \\
\hline & & Often & 17 & 11.41 \\
\hline & & Sometimes & 9 & 6.04 \\
\hline & & Rarely & 19 & 12.75 \\
\hline & & Not at All & 93 & 62.42 \\
\hline \multirow[t]{5}{*}{6} & \multirow{5}{*}{$\begin{array}{l}\text { I have no problem at all to lead my life with common } \\
\text { people in society }\end{array}$} & Always & 17 & 11.41 \\
\hline & & Often & 32 & 21.48 \\
\hline & & Sometimes & 21 & 14.09 \\
\hline & & Rarely & 35 & 23.49 \\
\hline & & Not at All & 44 & 29.53 \\
\hline \multirow[t]{5}{*}{7} & \multirow[t]{5}{*}{ My friends avoid to me in any subject of work } & Always & 7 & 4.70 \\
\hline & & Often & 33 & 22.15 \\
\hline & & Sometimes & 41 & 27.52 \\
\hline & & Rarely & 37 & 24.83 \\
\hline & & Not at All & 31 & 20.80 \\
\hline \multirow[t]{5}{*}{8} & \multirow{5}{*}{$\begin{array}{l}\text { People say that I have no role, because I am physically } \\
\text { defects }\end{array}$} & Always & 5 & 3.36 \\
\hline & & Often & 21 & 14.09 \\
\hline & & Sometimes & 40 & 26.85 \\
\hline & & Rarely & 35 & 23.49 \\
\hline & & Not at All & 48 & 32.21 \\
\hline \multirow[t]{5}{*}{9} & \multirow[t]{5}{*}{ I am very much hopeful to establish my-self } & Always & 47 & 31.54 \\
\hline & & Often & 37 & 24.83 \\
\hline & & Sometimes & 22 & 14.77 \\
\hline & & Rarely & 35 & 23.49 \\
\hline & & Not at All & 8 & 5.37 \\
\hline \multirow[t]{5}{*}{10} & \multirow[t]{5}{*}{ I think that God is responsible for my physical defect } & Always & 9 & 6.04 \\
\hline & & Often & 13 & 8.73 \\
\hline & & Sometimes & 34 & 22.82 \\
\hline & & Rarely & 37 & 24.83 \\
\hline & & Not at All & 56 & 37.58 \\
\hline \multirow[t]{5}{*}{11} & \multirow[t]{5}{*}{ I think it is better to die than to live on depending other } & Always & 0 & 0 \\
\hline & & Often & 9 & 6.04 \\
\hline & & Sometimes & 16 & 10.74 \\
\hline & & Rarely & 21 & 14.09 \\
\hline & & Not at All & 103 & 69.13 \\
\hline \multirow[t]{5}{*}{12} & \multirow[t]{5}{*}{ I feel lack of my self-prestised if people make fun of me } & Always & 9 & 6.04 \\
\hline & & Often & 16 & 10.74 \\
\hline & & Sometimes & 31 & 20.80 \\
\hline & & Rarely & 44 & 29.53 \\
\hline & & Not at All & 49 & 32.89 \\
\hline \multirow[t]{2}{*}{13} & \multirow{2}{*}{$\begin{array}{l}\text { Person of opposite gender don't feel attracted to me for } \\
\text { my physical defect }\end{array}$} & Always & 19 & 12.70 \\
\hline & & Often & 34 & 22.89 \\
\hline
\end{tabular}




\begin{tabular}{|c|c|c|c|c|}
\hline & & Sometimes & 36 & 24.16 \\
\hline & & Rarely & 29 & 19.64 \\
\hline & & Not at All & 31 & 20.81 \\
\hline 14 & If anybody wounds me mentally I feel my-self broken & Always & 21 & 14.09 \\
\hline & down & Often & 29 & 19.46 \\
\hline & & Sometimes & 49 & 32.89 \\
\hline & & Rarely & 33 & 22.15 \\
\hline & & Not at All & 17 & 11.41 \\
\hline 15 & I can express my-self in front of other quite easily & Always & 30 & 2014 \\
\hline & & Often & 36 & 24.16 \\
\hline & & Sometimes & 21 & 14.09 \\
\hline & & Rarely & 55 & 36.91 \\
\hline & & Not at All & 7 & 4.70 \\
\hline 16 & I think my classmates are how much better than me & Always & 13 & 8.72 \\
\hline & & Often & 26 & 17.45 \\
\hline & & Sometimes & 35 & 23.49 \\
\hline & & Rarely & 28 & 18.80 \\
\hline & & Not at All & 47 & 31.54 \\
\hline 17 & I think there is nothing for me in this world & Always & 5 & 3.34 \\
\hline & & Often & 17 & 11.42 \\
\hline & & Sometimes & 25 & 16.78 \\
\hline & & Rarely & 44 & 29.53 \\
\hline & & Not at All & 58 & 38.93 \\
\hline 18 & Though I am physically challenge, I am allowed to do & Always & 9 & 6.04 \\
\hline & every work & Often & 24 & 16.11 \\
\hline & & Sometimes & 15 & 10.07 \\
\hline & & Rarely & 45 & 30.20 \\
\hline & & Not at All & 56 & 37.58 \\
\hline 19 & I think I am the most unfortunate person in this world & Always & 5 & 3.34 \\
\hline & & Often & 19 & 12.75 \\
\hline & & Sometimes & 35 & 23.49 \\
\hline & & Rarely & 31 & 20.82 \\
\hline & & Not at All & 59 & 39.60 \\
\hline 20 & I don't have any hesitation to mix up with my & Always & 27 & 18.12 \\
\hline & classmates and teachers & Often & 41 & 27.52 \\
\hline & & Sometimes & 11 & 7.38 \\
\hline & & Rarely & 31 & 20.81 \\
\hline & & Not at All & 39 & 26.17 \\
\hline 21 & I can do any work quite easily though I am physically & Always & 29 & 19.46 \\
\hline & defect & Often & 44 & 29.53 \\
\hline & & Sometimes & 26 & 17.45 \\
\hline & & Rarely & 39 & 26.17 \\
\hline
\end{tabular}




\begin{tabular}{|c|c|c|c|c|}
\hline & & Not at All & 11 & 7.39 \\
\hline \multirow[t]{5}{*}{22} & \multirow[t]{5}{*}{ Teachers don't pay any important to me } & Always & 5 & 3.36 \\
\hline & & Often & 21 & 14.09 \\
\hline & & Sometimes & 9 & 6.04 \\
\hline & & Rarely & 23 & 15.44 \\
\hline & & Not at All & 91 & 61.07 \\
\hline \multirow[t]{5}{*}{23} & \multirow[t]{5}{*}{ My classmate behave or look at with me hatefuly } & Always & 3 & 2.01 \\
\hline & & Often & 11 & 7.38 \\
\hline & & Sometimes & 17 & 11.41 \\
\hline & & Rarely & 49 & 32.89 \\
\hline & & Not at All & 69 & 46.31 \\
\hline \multirow[t]{5}{*}{24} & \multirow[t]{5}{*}{ I don't have any lack of self-confidence } & Always & 13 & 8.72 \\
\hline & & Often & 19 & 12.75 \\
\hline & & Sometimes & 29 & 19.46 \\
\hline & & Rarely & 49 & 32.90 \\
\hline & & Not at All & 39 & 26.17 \\
\hline \multirow[t]{5}{*}{25} & \multirow[t]{5}{*}{ I think my-self inferior to other } & Always & 9 & 6.04 \\
\hline & & Often & 24 & 16.11 \\
\hline & & Sometimes & 30 & 20.13 \\
\hline & & Rarely & 39 & 26.18 \\
\hline & & Not at All & 47 & 31.54 \\
\hline \multirow[t]{5}{*}{26} & \multirow{5}{*}{$\begin{array}{l}\text { I feel my-self very much ashamed to go to any social } \\
\text { functions }\end{array}$} & Always & 3 & 2.01 \\
\hline & & Often & 13 & 8.72 \\
\hline & & Sometimes & 31 & 20.81 \\
\hline & & Rarely & 38 & 25.50 \\
\hline & & Not at All & 64 & 42.96 \\
\hline \multirow[t]{5}{*}{27} & \multirow{5}{*}{$\begin{array}{l}\text { I don't feel my-self different from others though I am } \\
\text { physically challenged }\end{array}$} & Always & 38 & 25.51 \\
\hline & & Often & 29 & 19.46 \\
\hline & & Sometimes & 21 & 14.10 \\
\hline & & Rarely & 26 & 17.44 \\
\hline & & Not at All & 35 & 23.49 \\
\hline \multirow[t]{5}{*}{28} & \multirow{5}{*}{$\begin{array}{l}\text { My friends and parent don't give me credit though I } \\
\text { perform well in any work }\end{array}$} & Always & 5 & 3.36 \\
\hline & & Often & 21 & 14.09 \\
\hline & & Sometimes & 31 & 20.81 \\
\hline & & Rarely & 51 & 34.23 \\
\hline & & Not at All & 41 & 27.51 \\
\hline \multirow[t]{5}{*}{29} & \multirow{5}{*}{$\begin{array}{l}\text { I think it better to go out from home because of my } \\
\text { physically defect }\end{array}$} & Always & 6 & 4.03 \\
\hline & & Often & 8 & 5.37 \\
\hline & & Sometimes & 10 & 6.71 \\
\hline & & Rarely & 46 & 30.87 \\
\hline & & Not at All & 79 & 53.02 \\
\hline 30 & I gate everything from home whatever I wish & Always & 71 & 47.65 \\
\hline
\end{tabular}




\begin{tabular}{|l|c|c|c|c|}
\hline \multirow{3}{*}{} & Often & 47 & 31.55 \\
\cline { 2 - 4 } & Sometimes & 19 & 12.75 \\
\cline { 2 - 4 } & Rarely & 9 & 6.04 \\
\cline { 2 - 4 } & Not at All & 3 & 2.01 \\
\hline
\end{tabular}

\section{Discussions}

Item No-1: The above table shows that out of 149 Differently Abled Students, $6.71 \%$, $18.12 \%, 28.19 \%, 20.81 \%$ and $26.17 \%$ Students have given their opinion at the level of Always, Often, and Sometimes, Rarely and Not at All against the Item No-1 respectively. So, we can say that most of the Differently Abled Students (28.19\%) think sometimes that they don't want to go out of home for their physical defectiveness.

Item No-2: The above table and figure show that out of 149 Differently Abled Students, $6.04 \%, 18.79 \%, 32.21 \%, 20.81 \%$ and $22.15 \%$ Students have given their opinion at the level of Always, Often, Sometimes, Rarely and Not at All against the Item No-2 respectively. So, we can say that most of the Differently Abled Students (32.21\%) think sometimes that they feel inferior in any subject.

Item No-3: The above table and figure show that out of 149 Differently Abled Students, $59.73 \%, 28.19 \%, 6.04 \%, 3.36 \%$ and $2.68 \%$ Students have given their opinion at the level of Always, Often, Sometimes, Rarely and Not at All against the Item No-3 respectively. So, we can say that most of the Differently Abled Students (59.73\%) think always that their relatives behave well with me.

Item No-4: The above table and figure show that out of 149Differently Abled Students, $4.70 \%, 16.78 \%, 14.09 \%, 30.20 \%$ and $34.23 \%$ Students have given their opinion at the level of Always, Often, Sometimes, Rarely and Not at All against the Item No-4 respectively. So, we can say that most of the Differently Abled Students (34.23\%) think not at all that they see that most of the people of society do not give them importance.

Item No-5: The above table and figure show that out of 149 Differently Abled Students, $7.38 \%, 11.41 \%, 6.04 \%, 12.752 \%$ and $62.42 \%$ Students have given their opinion at the level of Always, Often, Sometimes, Rarely and Not at All against the Item No-5 respectively. So, we can say that most of the Differently Abled Students (62.42\%) think not at all that their sisters and brothers are dearer than them to their parents.

Item No-6: The above table and figure show that out of 149 Differently Abled Students, $11.41 \%, 21.48 \%, 14.09 \%, 23.49 \%$ and $29.53 \%$ Students have given their opinion at the level of Always, Often, Sometimes, Rarely and Not at All against the Item No-6 respectively. So, we can say that most of the Differently Abled Students (29.53\%) think not at all that there has no problem at all to lead their life with common people in society

Item No-7: The above table and figure show that out of 149 Differently Abled Students, $4.70 \%, 22.15 \%, 27.52 \%, 24.83 \%$ and $20.80 \%$ Students have given their opinion at the level of Always, Often, Sometimes, Rarely and Not at All against the Item No-7 respectively. So, we can say that most of the Differently Abled Students (27.52\%) think rarely that their friends avoid them in any subject of work.

Item No-8: The above table and figure show that out of 149 Differently Abled Students, $3.36 \%, 14.09 \%, 26.85 \%, 23.49 \%$ and $32.21 \%$ Students have given their opinion at the level of 
Always, Often, Sometimes, Rarely and Not at All against the Item No- 8 respectively. So, we can say that most of the Differently Abled Students (32.21\%) think not at all that People say that they have no role because there have physically handicap.

Item No-9: The above table and figure show that out of 149 Differently Abled Students, $31.54 \%, 24.83 \%, 14.77 \%, 23.49 \%$ and $5.37 \%$ Students have given their opinion at the level of Always, Often, Sometimes, Rarely and Not at All against the Item No-9 respectively. So, we can say that most of the Differently Abled Students (31.54\%) think always that they have very much hope to establish them-self.

Item No-10: The above table and figure show that out of 149 Differently Abled Students, $6.04 \%, 8.73 \%, 22.82 \%, 24.83 \%$ and $37.58 \%$ Students have given their opinion at the level of Always, Often, Sometimes, Rarely and Not at All against the Item No-10 respectively. So, we can say that most of the Differently Abled Students (37.58\%) think not at all that God is responsible for their physical defect.

Item No-11: The above table and figure show that out of 149 Differently Abled Students, $0 \%, 6.04 \%, 10.74 \%, 14.09 \%$ and $69.13 \%$ Students have given their opinion at the level of Always, Often, Sometimes, Rarely and Not at All against the Item No-11 respectively. So, we can say that most of the Differently Abled Students (69.13\%) think not at all that they think it is better to die than to live on depending on others.

Item No-12: The above table and figure show that out of 149 Differently Abled Students, $6.04 \%, 10.74 \%, 20.80 \%, 29.53 \%$ and $32.89 \%$ Students have given their opinion at the level of Always, Often, Sometimes, Rarely and Not at All against the Item No-12 respectively. So, we can say that most of the Differently Abled Students (32.89\%) think rarely that they feel lack of their self-prestised if people make fun of them.

Item No-13: The above table and figure show that out of 149 Differently Abled Students, $12.70 \%, 22.89 \%, 24.16 \%, 19.64 \%$ and $20.81 \%$ Students have given their opinion at the level of Always, Often, Sometimes, Rarely and Not at All against the Item No-13 respectively. So, we can say that most of the Differently Abled Students (24.16\%) think often that Persons of the opposite gender don't feel attracted to them for their physical defect.

Item No-14: The above table and figure show that out of 149 Differently Abled Students, $14.09 \%, 19.45 \%, 32.80 \%, 22.15 \%$ and $11.41 \%$ Students have given their opinion at the level of Always, Often, Sometimes, Rarely and Not at All against the Item No-14 respectively. So, we can say that most of the Differently Abled Students (32.80\%) think sometimes that If anybody wounds them mentally, their self-confidence was broken down.

Item No-15: The above table and figure show that out of 149 Differently Abled Students, $20.14 \%, 24.16 \%, 14.09 \%, 36.91 \%$ and $4.70 \%$ Students have given their opinion at the level of Always, Often, Sometimes, Rarely and Not at All against the Item No-15 respectively. So, we can say that most of the Differently Abled Students (36.91\%) think rarely that they can express them-self in front of others quite easily.

Item No-16: The above table and figure show that out of 149 Differently Abled Students, $8.12 \%, 17.45 \%, 23.49 \%, 18.80 \%$ and $31.54 \%$ Students have given their opinion at the level of Always, Often, Sometimes, Rarely and Not at All against the Item No-16 respectively. So, we can say that most of the Differently Abled Students (31.54\%) think sometimes that they think their classmates are how much better than them. 
Item No-17: The above table and figure show that out of 149 Differently Abled Students, $3.34 \%, 11.42 \%, 16.78 \%, 29.53 \%$ and $38.93 \%$ Students have given their opinion at the level of Always, Often, Sometimes, Rarely and Not at All against the Item No-17 respectively. So, we can say that most of the Differently Abled Students (38.93\%) think not at all that there is nothing for them in this world.

Item No-18: The above table and figure show that out of 149 Differently Abled Students, $6.04 \%, 16.11 \%, 10.07 \%, 30.20 \%$ and $37.58 \%$ Students have given their opinion at the level of Always, Often, Sometimes, Rarely and Not at All against the Item No-18 respectively. So, we can say that most of the Differently Abled Students (37.58\%) think not at all that they thought they are physically challenge they are allowed to do every work.

Item No-19: The above table and figure show that out of 149 Differently Abled Students, $3.34 \%, 12.75 \%, 23.49 \%, 20.82 \%$ and $39.60 \%$ Students have given their opinion at the level of Always, Often, Sometimes, Rarely and Not at All against the Item No-19 respectively. So, we can say that most of the Differently Abled Students (39.60\%) think not at all that they are the most unfortunate person in this world.

Item No-20: The above table and figure show that out of 149 Differently Abled Students, $18.12 \%, 27.52 \%, 7.38 \%, 20.81 \%$ and $26.17 \%$ Students have given their opinion at the level of Always, Often, Sometimes, Rarely and Not at All against the Item No-20 respectively. So, we can say that most of the Differently Abled Students (27.52\%) think often that they don't have any hesitation to mix up with their classmates and teachers.

Item No-21: The above table and figure show that out of 149 Differently Abled Students, $19.46 \%, 29.53 \%, 17.45 \%, 26.17 \%$ and $7.39 \%$ Students have given their opinion at the level of Always, Often, Sometimes, Rarely and Not at All against the Item No-21 respectively. So, we can say that most of the Differently Abled Students (29.53\%) think often that they can do any work quite easily though they are physically challenged.

Item No-22: The above table and figure show that out of 149 Differently Abled Students, $3.36 \%, 14.09 \%, 6.04 \%, 15.44 \%$ and $61.07 \%$ Students have given their opinion at the level of Always, Often, Sometimes, Rarely and Not at All against the Item No-22 respectively. So, we can say that most of the Differently Abled Students (61.07\%) think not at all that their Teachers don't pay any importance to them.

Item No-23: The above table and figure show that out of 149 Differently Abled Students, $2.01 \%, 7.38 \%, 11.41 \%, 32.89 \%$ and $46.31 \%$ Students have given their opinion at the level of Always, Often, Sometimes, Rarely and Not at All against the Item No-23 respectively. So, we can say that most of the Differently Abled Students $(46.31 \% \& 32.89 \%)$ think not at all \& rarely that their classmate behaves or look at with them hatefully.

Item No-24: The above table and figure show that out of 149 Differently Abled Students, $8.72 \%, 12.75 \%, 19.46 \%, 32.90 \%$ and $26.17 \%$ Students have given their opinion at the level of Always, Often, Sometimes, Rarely and Not at All against the Item No-24 respectively. So, we can say that most of the Differently Abled Students (32.90\%) think rarely that they don't have any lack of self-confidence.

Item No-25: The above table and figure show that out of 149 Differently Abled Students, $6.04 \%, 16.11 \%, 20.13 \%, 26.18 \%$ and $31.54 \%$ Students have given their opinion at the level of Always, Often, Sometimes, Rarely and Not at All against the Item No-25 respectively. So, 
we can say that most of the Differently Abled Students $(31.54 \% \& 26.18 \%)$ think not at all \& rarely that they are him-self inferior to other.

Item No-26: The above table and figure show that out of 149 Differently Abled Students, $2.01 \%, 8.72 \%, 20.81 \%, 25.50 \%$ and $42.96 \%$ Students have given their opinion at the level of Always, Often, Sometimes, Rarely and Not at All against the Item No-26 respectively. So, we can say that most of the Differently Abled Students (42.96\%) think not at all that they feel them-self very much ashamed to go to any social functions.

Item No-27: The above table and figure show that out of 149 Differently Abled Students, $25.51 \%, 19.46 \%, 14.10 \%, 17.44 \%$ and $23.49 \%$ Students have given their opinion at the level of Always, Often, Sometimes, Rarely and Not at All against the Item No-27 respectively. So, we can say that most of the Differently Abled Students $(23.49 \%$ \& $25.51 \%)$ think not at all \& always that they don't feel them-self different from others though they are physically challenged.

Item No-28: The above table and figure show that out of 149 Differently Abled Students, $3.36 \%, 14.09 \%, 20.81 \%, 34.23 \%$ and $27.51 \%$ Students have given their opinion at the level of Always, Often, Sometimes, Rarely and Not at All against the Item No-28 respectively. So, we can say that most of the Differently Abled Students $(34.23 \% \& 27.51 \%)$ think rarely and not at all that their friends and parent don't give them credit though they perform well in any work.

Item No-29: The above table and figure show that out of 149 Differently Abled Students, $4.03 \%, 5.37 \%, 6.71 \%, 30.87 \%$ and $53.02 \%$ Students have given their opinion at the level of Always, Often, Sometimes, Rarely and Not at All against the Item No-29 respectively. So, we can say that most of the Differently Abled Students (53.02\%) think not at all that they are like to go out from home because of their physical defect.

Item No-30: The above table and figure show that out of 149 Differently Abled Students, $47.65 \%, 3.55 \%, 12.75 \%, 6.04 \%$ and $2.01 \%$ Students have given their opinion at the level of Always, Often, Sometimes, Rarely and Not at All against the Item No-30 respectively. So, we can say that most of the Differently Abled Students (47.65\%) think always that they gate everything from home whatever they wish.

\section{Conclusion}

From the above discussion the Infinity Complex of Differently Abled Students is a very important issue in education as well as a social area. In this present study found that the level of Infinity Complex of Differently Abled Students is Moderate. Most of the Differently Abled Students of West Bengal have given their opinion on the 'Not at all' option of the mentioned items. In this study revealed that some of the Differently Abled Students have given their opinion on the 'Sometimes' option of the mentioned items and also observed that some of the Differently Abled Students have given their opinion on the 'Always' option of the mentioned items. It also explored that a few Differently Abled Students have given their opinion on the 'Rarely' and 'Often' option of the mentioned items. This study shows that differently Abled students in West Bengal schools do not have intensified Inferiority Complex. It is understood that people who have Infinity Complex in their life can adapt themselves to different environmental conditions. Different aspects of society remain unclear 
to them. As a result, they often find themselves in isolation. From this it is understood that a kind of negative mental tendency is seen in such people. This is the kind of complex that creates inferiority in individuals. Here are some tips to help Differently Abled Students learn about the Inferiority Complex. And at the same time some items are given and which have been analyzed.

\section{Reference:}

1. Ala, M. (1957). Overcoming an Inferiority Complex- Sermon Delivered at Dexter Avenue Baptist Church. The Martin Luther King, Jr. Papers Project, 303-316.

2. Alphen A. W. V. (1969). A Study of the Effects of Inferiority Feelings on the Life and Works of Franz Kafka. Louisiana State University Historical Dissertations and Theses, 1626. https://digitalcommons.lsu.edu/gradschool_disstheses/1626

3. Banerjee, Sumedha (2018). Personality traits among Hearing and Speech impaired Students and Normal Students: A Review. International Conference on Research Development in Arts, Social Science, Education and Sports, 54-62.

4. Devi, D. Uma and Reddy, P. Adinarayana. (2016). Problems of Children with Special Needs (CWSNs) in Accessing the Education: Role of Barrier free Environment - A Case Study of India. Bulgarian Journal of Science and Education Policy (BJSEP), 10(1), 90-105

5. Dhara, R and Barman, P. (2020). Inferiority Complex, Adjustment problem and Academic Performance of Differently-Abled Students in the State of West Bengal. Humanities \& Social Sciences Reviews, 8(3), 1383-1394. https://doi.org/10.18510/hssr.2020.83139

6. Han, Eun-Mi. (2011). A Pastoral Approach to the Problem of an Inferiority Complex for Workers in the Korean Context. University of the Free State Faculty of Theology- (Practical Theology), 1-141.

7. Ibrahim A. K and Okopi, F. O. (2014). Effect Of Mainstreaming Education On The Academic Achievement Of Mildly Impaired Lower Basic Three Pupils In Northwest Nigeria. IOSR Journal of Research \& Method in Education (IOSR-JRME), 4(4), 9-15. www.iosrjournals.org

8. Idrees, Balal and Ilyas, Rehan (2012). Discrimination and Stigmatization of Physically

Disabled Student in a General Educational Environment in Pakistan: A Case Study. Academic Research International, 2(2), 622-626. www.journals.savap.org.pk

9. Ikram, Faiza and Waheed, Sadia. (2018). Inferiority Complex: A Character Analysis of Elif Shafak's Honour. International Journal of Scientific and Research Publications, 8(10), 1-5. http://dx.doi.org/10.29322/IJSRP.8.10.2018.p8202

10. Jayapaul, A. (2015). Inferiority Complex in relation to Their Academic Achievement Among Higher Secondary Students. An international Refereed, Peered Reviewed and Index Quarterly Journal In Arts, Commerce, Education and Social Science, 4(3), 19-20.

11. Kalavani, G. (2017). A study on Inferiority Complex of High School Students in relation to Their Academic Achievement in Vellore District. International Educational Scientific Research Journal, 3(5), 94-96.

12. Lin, T. (1997). Inferiority Complex- Prevention in Children and Relief from It in Adults, 1-5. www.bsmi.org.

13. Mishra, B. (2018). A Study on the Level of Inferiority Complexity of Secondary Students. IAETSD Journal for Advanced Research in Applied Sciences, 5(3). 504-510.

14. Mishar et al. (2014). Analyzing Educational Status of Children with Disability and Identifying Critical Intervention to Promote their Enrollment, Retention and Success in Schools. Dynamic Institute of Research and Development (P) Limited, Kathmandu (O): Department of Education (MoE), Sanothimi, Bhaktapur, Nepal, 1-79. www.randdnepal.com 
15. Sumarsono, I. (2019). The Inferiority Complex of Laura Wingfield in Tennessee William's the Glass Menagerie. Dinamika : Jurnal Sastra dan Budaya, 7(1), 716-723.

16. Varghese, S. (2016). Application of IoT to improve the life style of differently abled people. IOSR Journal of Computer Engineering (IOSR-JCE), 29-34. www.iosrjournals.org

17. Uralovich, K. A. (2019). Psycho Correction of the Inferiority Complex of the People with Physical Disability . European Journal of Research and Reflection in Educational Sciences, 7(5), 36-41. www.idpublications.org 